Research Report 1630

\title{
Feasibility of Using Realistic Job Previews in the Army Recruiter Training Process
}

\author{
Samuel B. Pond, III, Thomas E. Powell, Jennifer J. Norton, \\ and Paul W. Thayer \\ North Carolina State University
}
Manpower and Personnel Policy Research Technical Area Timothy W. Elig, Acting Chief
Manpower and Personnel Research Division Zita M. Simutis, Director

U.S. Army Research Institute for the Behavioral and Social Sciences 5001 Eisenhower Avenue, Alexandria, Virginia 22333-5600

Office, Deputy Chief of Staff for Personnel

Department of the Army

October 1992 